\title{
Smiles Rearrangement in the Synthesis of Di- and Triiodinated 5- (Acylamino)-1,3-Benzenedicarboxamides
}

\author{
Pier Lucio Anelli, Marino Brocchetta, Enrico Cappelletti*, Andrea Ferraris and Veronica Vincenzi
}

Centro Ricerche Bracco, Bracco Imaging spa, via Ribes 5, 10010 Colleretto Giacosa (TO), Italy

\begin{abstract}
Both the number and the position of iodine atoms on the aromatic ring of polyiodinated $N, N$ '-bis $(2,3-$ dihydroxypropyl)-5-[2-methylamino-2-oxoethoxy]-1,3-benzenedicarboxamides are crucial to define the structure of the product obtained by treatment with aqueous $\mathrm{NaOH}$. The 2,6-diiodo and the 2,4,6-triiodo derivatives give the corresponding Smiles rearrangement products in 77 and $96 \%$ yields, respectively. Conversely, under the same conditions, the 2,4diiodo isomer predominantly undergoes hydrolysis of the phenoxyacetamide moiety.
\end{abstract}

Keywords: Iodinated X-ray contrast media, Smiles rearrangement, Hydrolysis, Jackson-Meisenheimer intermediates, Computational studies.

\section{INTRODUCTION}

The Smiles rearrangement is industrially applied to the preparation of Iomeprol (1, N,N'-bis(2,3-dihydroxypropyl)5-[(hydroxyacetyl)methylamino]-2,4,6-triiodo-1,3-benzenedicarboxamide), a widely used X-ray contrast agent, according to a process [1a-d] which is more environmental friendly than the one previously used [2] as most of the steps are run in water, thus avoiding potentially dangerous solvents. The final Smiles rearrangement of $\mathbf{2}$ in the presence of aqueous $\mathrm{NaOH}$ (Scheme 1) is possible because of: $i$ ) its stability towards hydrolysis [1a-d,3]; ii) the presence of the electron withdrawing iodine atoms in ortho and para with respect to the position where the rearrangement occurs.<smiles>[R]NC(=O)c1c(I)c(C(N)=O)c(I)c(N(C)C(=O)CO)c1I</smiles>
2

$$
\mathrm{R}=\mathrm{CH}_{2} \mathrm{CH}(\mathrm{OH}) \mathrm{CH}_{2} \mathrm{OH}
$$

1 Iomeprol

Scheme 1. Reagents and conditions: (i) aq. $\mathrm{NaOH}, 5 \mathrm{~h} ; 95^{\circ} \mathrm{C} ; 85 \%$.

The second issue has been discussed in several papers [4], although Smiles rearrangements on aromatic substrates deactivated towards nucleophilic substitutions have also been reported [5]. However, it is important to underline that, in cases involving the migration of an aromatic ring from oxygen to amide nitrogen, strictly anhydrous conditions were always used. In this context, excluding the examples we already reported [3], no Smiles rearrangement was ever successfully performed in either water or aqueous media. Our experience on the Smiles rearrangement of $\mathrm{N}$-methyl phenoxyacetamides performed with aqueous bases had shown a

*Address correspondence to this author at the Centro Ricerche Bracco, Bracco Imaging spa, via Ribes 5, 10010 Colleretto Giacosa (TO), Italy; E-mail: Enrico.Cappelletti@bracco.com completely different behaviour for $\mathbf{2}$ and the corresponding substrate without the iodine atoms (i.e. $N, N^{\prime}$-bis(2,3dihydroxypropyl)-5-[2-methylamino-2-oxoethoxy]-1,3-benzenedicarboxamide) [3]. While the former rearranged almost quantitatively, the latter was completely hydrolysed to the corresponding phenoxyacetic acid. The aims of this work are: $i)$ to investigate whether treatment with aqueous $\mathrm{NaOH}$ of di-iodinated isomers $\mathbf{3}$ and $\mathbf{4}$ (Scheme 2) leads to the corresponding Smiles rearrangement products (i.e. 5 and $\mathbf{6}$, which are possible side-products in the synthesis of $\mathbf{1}$ ); ii) to elucidate, on the basis of computational studies, the role played by the iodine atoms on the different behaviour shown by the two isomers 3 and $\mathbf{4}$.<smiles>[R]NC(=O)c1c(I)c(OCC(=O)NC)c(I)c(C(=O)N[R])c1I</smiles><smiles>[R]CC(O)CO</smiles>

Scheme 2. Reagents and conditions: (i) $\mathrm{H}_{2} \mathrm{O}, \mathrm{ICl} / \mathrm{HCl}(1.4 \mathrm{~mol}$ equiv.), aq. $\mathrm{NaOH}$ to maintain $\mathrm{pH} 1.5,3 \mathrm{~h}, 5-7{ }^{\circ} \mathrm{C}$; (ii) $\mathrm{H}_{2} \mathrm{O}$, aq. $\mathrm{NaOH}$ to $\mathrm{pH} 7, \mathrm{ClCH}_{2} \mathrm{CONHCH}_{3}, 7 \mathrm{~h}, 95^{\circ} \mathrm{C}$, preparative HPLC separation, $1.1 \%(3), 1.9 \%(4)$.

\section{RESULTS AND DISCUSSION}

The synthesis of the starting materials for the study was performed according to Scheme 2. Iodination of $N, N^{\prime}$-bis (2,3-dihydroxypropyl)-5-hydroxy-1,3-benzenedicarboxamide with 1.4 mol equiv. of $\mathrm{ICl}$, instead of the theoretical $3 \mathrm{~mol}$ equiv required to afford $\mathbf{1}$, gave a mixture which was sub- 
jected to alkylation reaction with $N$-methyl chloroacetamide [1d]. After concentration and filtration of precipitated 2, a preparative HPLC separation performed on the mother liquor afforded the diiodinated regioisomers 3 and 4 .

The synthesis of $\mathbf{5}$ and $\mathbf{6}$, i.e. the reference compounds to test the rearrangement of $\mathbf{3}$ and $\mathbf{4}$, was initially approached by controlled monodeiodination of $\mathbf{1}$ (Scheme $\mathbf{3}$ ). Under the reaction conditions $\left(\mathrm{NaBH}_{4}, \mathrm{H}_{2} \mathrm{O}\right)$, the reaction gave a mixture of products, from which the major product 5 could be obtained pure by preparative HPLC [6]. A second approach was then pursued to prepare both diiodinated regioisomers by selective diiodination of 7 .<smiles>[R]NC(=O)c1cc(N)cc(C(=O)N[R])c1</smiles><smiles>[R]NC(=O)c1c(I)c(N)cc(C(=O)O[R])c1I</smiles><smiles>[R]NC(=O)c1cc(C(N)=O)c(I)c(N)c1I</smiles><smiles>[R]NC(=O)c1c(I)c(NC(=O)OCC(C)=O)cc(C(=O)O)c1I</smiles><smiles>[R]NC(=O)c1c(C)c(C(=O)O[R])cc(NC(=O)CO)c1I</smiles>

10



Scheme 3. Reagents and conditions: (i) $\mathrm{H}_{2} \mathrm{O} \mathrm{pH} \mathrm{1,} \mathrm{ICl/HCl,} 2$ h, 1$4{ }^{\circ} \mathrm{C}, 43 \%$; (ii) $\mathrm{DMAc}, \mathrm{CH}_{3} \mathrm{COOCH}_{2} \mathrm{COCl}, 11 \mathrm{~h}, 35{ }^{\circ} \mathrm{C}$; (iii) $\mathrm{H}_{2} \mathrm{O} / \mathrm{MeOH}, \mathrm{NaOH}$ to maintain $\mathrm{pH} 9.5,12 \mathrm{~h}, 35^{\circ} \mathrm{C}, 82 \%$ (from 8); (iv) DMF, $\mathrm{MeONa}, \mathrm{CH}_{3} \mathrm{I}, 24 \mathrm{~h}, 20{ }^{\circ} \mathrm{C}, 52 \%$; (v) $\mathrm{NaBH}_{4}$ in aq. $\mathrm{NaOH}, \mathrm{HCl}, 1.5 \mathrm{~h}, 25-50{ }^{\circ} \mathrm{C}$, preparative HPLC separation, $20 \%$.

To our delight, the reaction was highly regioselective and the formation of the 4,6-diiodo regioisomer was not observed and only the 2,4-diiodo isomer $\mathbf{8}$ was obtained. The latter was peracylated with acetoxyacetyl chloride, deprotected and, finally, $\mathrm{N}$-methylated to afford $\mathbf{5}$. None of the above routes proved successful to afford compound $\mathbf{6}$.

The industrial conditions used [7] to transform 2 into $\mathbf{1}$ via Smiles rearrangement with substoichiometric amount of $\mathrm{NaOH}$ give $\mathbf{1}$ in almost quantitative yield. Indeed, at the end of the reaction the content of $\mathbf{1}$ is about $96 \%$ while $\mathbf{2}$, which is in equilibrium, is reduced to $1.5-2 \%$. Very small amounts of the phenoxyacetic acid produced by hydrolysis of $\mathbf{2}$ and the benzoxazinone derivative through cyclisation of the hydroxy group of the glycolic moiety of $\mathbf{1}$ with one of the ortho iodine atoms are also present, but their formation can be kept under control [3]. When we reacted $\mathbf{3}$ under similar conditions (Scheme 4), it was clear that a Smiles rearrangement was not occurring. Indeed, a substoichiometric amount of $\mathrm{NaOH}$ was not sufficient, as it should be for a secondary phenoxyacetamide, and the conversion of $\mathbf{3}$ could only be completed after addition of 1 mol equiv. of $\mathrm{NaOH}$. However, the main product was $\mathbf{1 1}$ [8].<smiles>[R]NC(=O)c1cc(OCC(=O)O[NH+]([R])C(=O)c2c(I)c(C(=O)N[R])cc(N(C)C(=O)O)c2I)c(I)c(C(=O)N[R])c1I</smiles><smiles>[R]NC(=O)c1cc(C(=O)N[R])c(I)c(OCC(=O)NC)c1I</smiles><smiles>[R]C=Cc1cc(C(=O)N[R])c(I)c2c1OCC(=O)N2C</smiles>

Scheme 4. Reagents and conditions: (i) $\mathrm{H}_{2} \mathrm{O}, \mathrm{NaOH}$ (0.1-1.0 mol equiv.), 3.5-6.0 h, $85-95{ }^{\circ} \mathrm{C}, 96 \%$ (1), $77 \%$ (6), 3\% (5).

Conversely, Smiles rearrangement of $\mathbf{4}$ afforded a complex mixture as it was partly hydrolysed to $\mathbf{1 2}$, while the expected rearranged derivative $\mathbf{6}$ also underwent the subsequent cyclisation to benzoxazinone $\mathbf{1 3}$, in its turn in equilibrium with the amino acid $\mathbf{1 4}$. Few trials [9] aimed at increasing the content of $\mathbf{6}$ in the reaction mixture met only with moderate success as its yield never exceeded 68\%. Although prolonging the reaction time could improve the conversion of $\mathbf{4}$, the amount of $\mathbf{6}$ did not raise because of the transformation into 13 and 14. However, a striking difference with the reaction outcome of $\mathbf{3}$ was observed, as $\mathbf{4}$ underwent rearrangement to a great extent and only a small amount of the starting material was hydrolysed [10]. The results were quite unexpected and we wondered if they could be related to electronic/steric features, in either the starting compounds and/or in the Jackson-Meisenheimer intermediates [4,11]. Computational studies were undertaken and molecules II, III and IV, 
deriving from $2, \mathbf{3}$ and $\mathbf{4}$ by substitution of the carboxamide moieties with hydrogen atoms (Fig. 1) were selected as model compounds on the basis of following considerations.<smiles>CNC(=O)COc1c(C)cc(I)cc1I</smiles><smiles>CNC(=O)COc1ccc(I)cc1C</smiles><smiles>CNC(=O)COc1c(I)cccc1I</smiles>

Fig. (1). Model compounds used for computational studies.

It is known that secondary aromatic carboxamides, bearing in ortho position one isopropyl substituent, which is as bulky as an iodine atom, adopt a conformation in which the aromatic ring and the plane of the carboxamide lie more or less in a orthogonal array. This prevents the electron delocalization originated from the $\pi$ conjugated system of the carboxamide residues [12]. Accordingly, since the carboxamides do not contribute to the electron density on the phenyl ring, it was reasonable to replace them with hydrogen atoms. This simplification also saved substantial computational time.

Accordingly, we performed ab initio calculations in the gas phase, at $\mathrm{HF} / 6-31 \mathrm{G}^{*}$ and at $\mathrm{HF} / 6-31+\mathrm{G}^{* *}$ levels of theory, to obtain the relative values of both potentials $(\Delta E)$ and Gibbs free energies $(\Delta G)$ of: $i)$ the anions deriving from the abstraction of the $\mathrm{NH}$ proton of the $\mathrm{N}$-methylamide moiety (An); ii) the transition states (TS); iii) the JacksonMeisenheimer intermediates (JM). We also monitored: $i$ ) the interatomic distance between the $\mathrm{C}_{5}$ carbon atom and the nitrogen atom of the methylamide moiety, i.e. the electrophilic and the nucleophilic sites, respectively, involved in the intramolecular cyclisation; ii) the $\mathrm{C}_{5}$ atomic charge, derived from electrostatic potential. The results, at both levels of theory, are reported in Table $\mathbf{1}$.

A few points deserve some comments: $i$ ) the atomic charge at $\mathrm{C}_{5}$ depends on both the number and the position of the iodine atoms on the benzene ring. Moving from the triiodinated compound II to the diiodinated IV, the charge diminishes as the inductive effect of the para iodine atom is lacking. The trend is amplified in the diiodinated compound III, because the lack of the ortho iodine atom is not compensated by the presence of the para one, which has a minor effect on the atomic charge; ii) the initial $\mathrm{C}_{5}-\mathrm{N}$ distance, especially in An species, is higher in III than in II and IV; iii) both the potential $(\Delta E)$ and the free energy $(\Delta G)$ hypersurfaces predict significant barriers exist for all the reactions from the reactants (An) to the transition states (TS). However, the barrier for compound III is higher and, furthermore, only the reactions of II and IV are thermodynamically favourable. The afore mentioned differences obviously depend on the presence of the bulky iodine atom in ortho position, which is crucial from a sterical point of view too. Indeed, in compound III, bearing an hydrogen atom in the ortho position, the side chain can occupy a conformational space otherwise sterically precluded in II and IV (Fig. 2).

Fig. (2) gives a picture of the reaction coordinate referred to compounds II and III, while those of compound IV, closely resembling that of II, is not shown. It is worth noting that the geometry of An II (and An IV) is more "product like" than the one of An III. Indeed, the bulky iodine atoms in positions 4 and 6 favour the perpendicular arrangement with respect to the benzene ring which is necessary for the formation of the five member ring in the JacksonMeisenheimer intermediate. Despite the adopted approximations, i.e. use of simplified molecules and gas phase reactions for the calculations, the results allow the interpretation of the behaviour of compounds $\mathbf{2 - 4}$ as follows: $i$ ) turning from 2 to $\mathbf{4}$ the lack of the para iodine makes the rearrangement slower and in the meantime some hydrolysis takes place; ii) the formation of the Jackson-Meisenheimer intermediate is more difficult for $\mathbf{3}$ than for $\mathbf{2}$ and $\mathbf{4}$, as the lack of the ortho iodine atom allows an arrangement of the side chain that increases the distance between the reactive centres. Moreover, the charge of $\mathrm{C}_{5}$ is lower and the energetic barrier becomes higher: the rearrangement becomes negligible and hydrolysis is the preferred reaction.

\section{CONCLUSIONS}

In diiodinated $N$-methylphenoxyacetamides, both the number and the position of the iodine atoms in the benzene

Table 1. $\mathrm{C}_{5}$ Atomic Charges, $\mathrm{C}_{5}-\mathrm{N}$ Distances, Relative Electronic and Gibbs Free Energies as Obtained from ab initio Calculations

\begin{tabular}{|c|c|c|c|c|}
\hline Species & C5-N Distance $(\AA)^{\mathrm{a}, \mathrm{b}}$ & C5 Atomic Charge ${ }^{a, b}$ (e.u.) & $\Delta \mathrm{E}^{\mathrm{a}, \mathrm{b}}\left(\right.$ kcal. $\left.\mathrm{mol}^{-1}\right)$ & $\Delta G^{\mathrm{a}}\left(\right.$ kcal. $\left.\mathrm{mol}^{-1}\right)$ \\
\hline TS II & $2.03(2.00)$ & $1.63(1.73)$ & $7.6(10.0)$ & 10.4 \\
\hline JM II & $1.47(1.47)$ & & $-12.9(-8.6)$ & -7.7 \\
\hline An III & $3.28(3.21)$ & $0.93(0.95)$ & $0.0(0.0)$ & 0.0 \\
\hline An IV & $2.75(2.78)$ & $1.20(1.34)$ & $0.0(0.0)$ & 0.0 \\
\hline TS IV & $2.00(1.98)$ & $1.48(1.71)$ & $10.3(11.6)$ & 12.7 \\
\hline JM IV & $1.47(1.47)$ & & $-8.2(-5.0)$ & -2.6 \\
\hline
\end{tabular}

${ }^{a}$ Calculated at $\mathrm{HF} / 6-31 \mathrm{G}^{*}$ level. ${ }^{\mathrm{b}}$ (In parentheses) calculated at $\mathrm{HF} / 6-31+\mathrm{G}^{* *}$ level. 


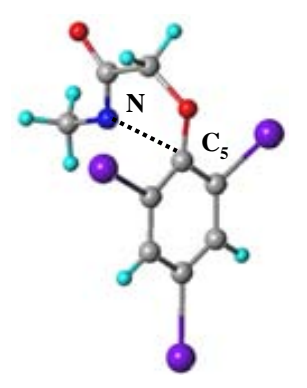

An II



An III

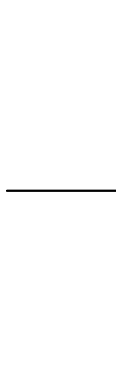

TS II
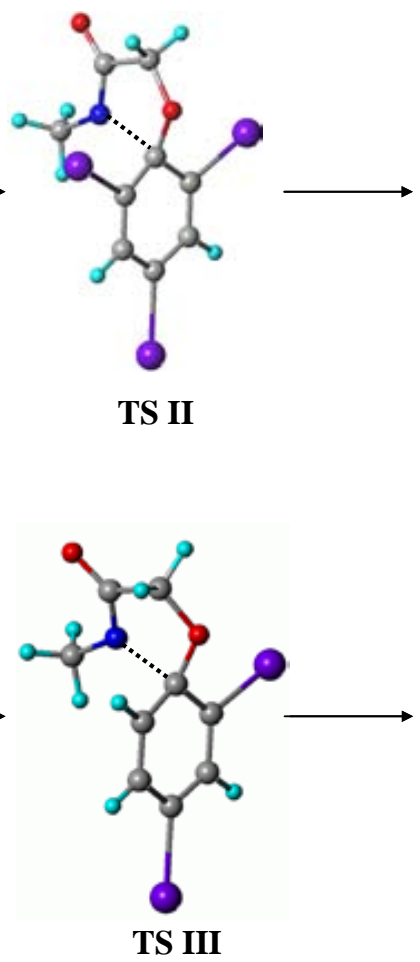

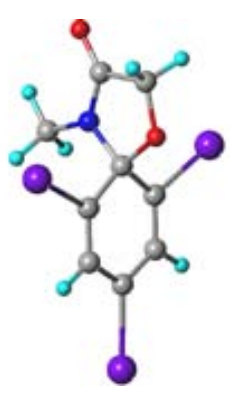

JM II



JM III

Fig. (2). HF/6-31+G** optimized structures for the cyclisation reactions of II and III.

ring are crucial to address the reaction in aqueous $\mathrm{NaOH}$ to either Smiles rearrangement or hydrolysis of the $\mathrm{N}$ methylamide moiety. The 2,4-diiodo isomer, $\mathbf{3}$, affords only the hydrolysis product whereas for the 2,6-diiodo isomer, $\mathbf{4}$, the rearrangement occurs to a large extent. The different behaviour of the two isomers can be explained on the basis of steric and electronic differences. Although the present study is limited to substrates $\mathbf{3}$ and $\mathbf{4}$ we think that it is indicative of a general behaviour. Accordingly, in order to synthesise iodinated acetanilides through Smiles rearrangement of the related phenoxyacetamides in water, it is mandatory that the latter have three iodine atoms ortho and para to the ipso aromatic carbon. Two iodine atoms are still sufficient, provided that they are in the ortho positions. The lack of one iodine atom in ortho position preferentially lead to the hydrolysis of the phenoxyacetamide.

\section{EXPERIMENTAL SECTION}

\section{General Information}

All reagents and solvents, obtained from commercial sources, were used without further purification. Melting points $\left({ }^{\circ} \mathrm{C}\right.$, uncorrected) were measured with a Büchi 510 instrument. TLC were carried out on $60 \mathrm{~F}_{254}$ silica gel plates using 6:3:1 $\mathrm{CHCl}_{3} / \mathrm{CH}_{3} \mathrm{OH} / 25 \% \mathrm{NH}_{4} \mathrm{OH}$ as the eluent, UV light $(254 \mathrm{~nm})$ and alkaline $\mathrm{KMnO}_{4}$ for the visualization. Preparative HPLC separations were performed with a Merck KGaA Prepbar 100 instrument using a Prepbar-Lichroprep RP18 column $(250 \times 50 \mathrm{~mm}, 10 \mu \mathrm{m})$ and methods A or B. Method A: injection: $20 \mathrm{~mL}$ of a $90 \mathrm{mg} / \mathrm{mL}$ solution in $\mathrm{H}_{2} \mathrm{O}$; mobile phase: a) $\mathrm{H}_{2} \mathrm{O}$, b) 1:1 $\mathrm{H}_{2} \mathrm{O} / \mathrm{CH}_{3} \mathrm{CN}$; timetable as follows: the percentage of b) is held 5 for $15 \mathrm{~min}$, then increased linearly to reach 35 at $40 \mathrm{~min}$, maintained for 15 min, increased linearly to reach 50 at $60 \mathrm{~min}$ and maintained for $10 \mathrm{~min}$; flow rate: $30 \mathrm{~mL} / \mathrm{min}$; UV detection: $240 \mathrm{~nm}$. Method B: injection: $200 \mathrm{~mL}$ of a $12 \mathrm{mg} / \mathrm{mL}$ solution in $\mathrm{H}_{2} \mathrm{O}$; mobile phase: a) $\mathrm{H}_{2} \mathrm{O}$, b) 99.5:0.5 $\mathrm{H}_{2} \mathrm{O} / \mathrm{CH}_{3} \mathrm{CN}$; timetable as follows: the percentage of b) is held 0 for $40 \mathrm{~min}$, then switched to 100 and maintained for $20 \mathrm{~min}$; flow rate: $30 \mathrm{~mL} / \mathrm{min}$ for $10 \mathrm{~min}$, then $70 \mathrm{~mL} / \mathrm{min}$ for $30 \mathrm{~min}$ and, again $30 \mathrm{~mL} / \mathrm{min}$ for $20 \mathrm{~min}$; UV detection: $254 \mathrm{~nm}$. Analytical HPLC analyses were performed with a HewlettPackard HP 1100 instrument using methods A, B, C and D. Method A: Zorbax SB-C18 column $(150 \times 4.6 \mathrm{~mm}, 3.5 \mu \mathrm{m})$; oven temperature: $60^{\circ} \mathrm{C}$; injection: $20 \mu \mathrm{L}$ of a $1 \mathrm{mg} / \mathrm{mL}$ solution in $\mathrm{H}_{2} \mathrm{O}$; mobile phase: a) $0.01 \mathrm{M} \mathrm{KH}_{2} \mathrm{PO}_{4}$, b) 1:1 0.01 $\mathrm{M} \mathrm{KH}_{2} \mathrm{PO}_{4} / \mathrm{CH}_{3} \mathrm{OH}$; timetable as follows: the percentage of b) is held 5 for $10 \mathrm{~min}$, then increased linearly to reach 35 at $25 \mathrm{~min}$ and maintained for 10 ; flow rate: $1 \mathrm{~mL} / \mathrm{min}$; UV detection: $240 \mathrm{~nm}$. Method B: Superspher RP-18 column (250 x $4.6 \mathrm{~mm}, 4 \mu \mathrm{m}$ ); oven temperature: $58{ }^{\circ} \mathrm{C}$; injection: $10 \mu \mathrm{L}$ of a $1 \mathrm{mg} / \mathrm{mL}$ solution in $\mathrm{H}_{2} \mathrm{O}$; mobile phase: a) $0.0125 \mathrm{M}$ $\mathrm{KH}_{2} \mathrm{PO}_{4}$, b) 55:40:3 $\mathrm{H}_{2} \mathrm{O} / \mathrm{CH}_{3} \mathrm{CN} / 2-\mathrm{BuOH}$; timetable as follows: the percentage of $b$ ) is held 3 for $5 \mathrm{~min}$, then increased linearly to reach 25 at $15 \mathrm{~min}$ and 75 at $30 \mathrm{~min}$; flow rate 1.2 $\mathrm{mL} / \mathrm{min}$; UV detection at $245 \mathrm{~nm}$. Method C: Lichrospher $100 \mathrm{RP}-18$ column $(250 \times 4 \mathrm{~mm}, 5 \mu \mathrm{m})$; oven temperature: $30{ }^{\circ} \mathrm{C}$; injection: $10 \mu \mathrm{L}$ of a $1 \mathrm{mg} / \mathrm{mL}$ solution in $\mathrm{H}_{2} \mathrm{O}$; mobile phase: a) $0.017 \mathrm{M} \mathrm{H}_{3} \mathrm{PO}_{4}$, b) $1: 1 \mathrm{H}_{2} \mathrm{O} / \mathrm{CH}_{3} \mathrm{CN}$; timetable as follows: the percentage of b) is held 5 for $5 \mathrm{~min}$, then increased linearly to reach 10 at $10 \mathrm{~min}$, held at 10 for $5 \mathrm{~min}$ then increased linearly to reach 50 at $20 \mathrm{~min}$ and held for 5 min; flow rate: $1 \mathrm{~mL} / \mathrm{min}$; UV detection: $245 \mathrm{~nm}$. Method D: Kromasil C4 column $(250 \times 4.6 \mathrm{~mm}, 5 \mu \mathrm{m})$; oven temperature: $40{ }^{\circ} \mathrm{C}$; injection: $15 \mu \mathrm{L}$ of a $1 \mathrm{mg} / \mathrm{mL}$ solution in $\mathrm{H}_{2} \mathrm{O}$; mobile phase: a) $0.017 \mathrm{M} \mathrm{H}_{3} \mathrm{PO}_{4}$, b) $\mathrm{CH}_{3} \mathrm{CN}$; timetable as follows: the percentage of $b$ ) is held 0 for $8 \mathrm{~min}$, then increased linearly to reach 50 at $40 \mathrm{~min}$; flow rate: 1.5 
$\mathrm{mL} / \mathrm{min}$; UV detection: $254 \mathrm{~nm}$. Mass spectra were acquired on a TSQ700 ThermoFinnigan Spectrometer using $\mathrm{CH}_{3} \mathrm{OH}$ as the solvent. ${ }^{13} \mathrm{C}$-NMR spectra were recorded at $298 \mathrm{~K}$ and 100.61 MHz with a Bruker DRX 400 spectrometer. The chemical shifts are given in $\delta$ units (ppm) relative to TMS $(\delta=0) .{ }^{1} \mathrm{H}-\mathrm{NMR}$ spectra are not reported since they are not useful for the assignment of the structures due to the broadness and extreme overlapping of the signals. Numbering of the basic skeleton of the molecule and mention of the neighbouring groups have been adopted to unambiguously identify the carbon atoms. Elemental analyses were carried out at the Redox Laboratories (Monza, Milano, Italy); the results are referred to the dry compound while the water percentage (K.F.) is reported in parentheses.

N,N'-Bis(2,3-dihydroxypropyl)-2,4-diiodo-5-[2-(methylamino)2-oxoethoxy]-1,3-benzenedicarboxamide (3) and $N, N$ 'bis(2,3-dihydroxypropyl)-4,6-diiodo-5-[2-(methylamino)-2oxoethoxy]-1,3-benzenedicarboxamide (4)

A solution of $N, N$ '-bis(2,3-dihydroxypropyl)-5-hydroxy1,3-benzenedicarboxamide [1d] (145 g; $0.44 \mathrm{~mol})$ in water (3 L) was iodinated at $5-7{ }^{\circ} \mathrm{C}$ with a $56.3 \%$ solution of $\mathrm{ICl}$ in $15 \%$ aq $\mathrm{HCl}$, maintaining the $\mathrm{pH}$ at 1.5 by addition of $2 \mathrm{M}$ $\mathrm{NaOH}$. The selectivity was poor as during the addition of the iodinating agent we mainly observed the presence of the starting material and $N, N$ '-bis(2,3-dihydroxypropyl)-5hydroxy-2,4,6-triiodo-1,3-benzenedicarboxamide. Only small amounts of diiodinated products (LC/MS), i.e. the precursors of $\mathbf{3}$ and $\mathbf{4}$, were detected. The reaction was stopped after $3 \mathrm{~h}$ and the addition of $1.4 \mathrm{~mol}$ equiv. of $\mathrm{ICl}$ in $\mathrm{HCl}$, when their sum was around $10 \%$. The reaction mixture was neutralised with $30 \%$ aq $\mathrm{NaOH}$, concentrated to about $0.7 \mathrm{~L}$ and precipitated $N, N$ '-bis(2,3-dihydroxypropyl)-5-hydroxy2,4,6-triiodo-1,3-benzenedicarboxamide was filtered. The mother liquor was subjected to alkylation with $\mathrm{N}$ methylchloroacetamide, according to the literature. ${ }^{[1]}$ After filtration of precipitated $\mathbf{2}$, the mother liquor was concentrated to about $0.2 \mathrm{~L}$, again filtered to get rid of some more 2 and subjected to preparative HPLC (method A). The crop $(5.7 \mathrm{~g})$ obtained by evaporation of the fractions containing almost pure 3 was dissolved in $\mathrm{H}_{2} \mathrm{O}(75 \mathrm{~mL})$ and the solution eluted through ion exchange resins (Amberlite Amberjet ${ }^{\circledR}$ $1200 \mathrm{H}, 9 \mathrm{~mL}$ and Relite $\left.{ }^{\circledR} \mathrm{MG} 1,6 \mathrm{~mL}\right)$. The neutral eluate was evaporated to dryness and the waxy residue $(5.1 \mathrm{~g})$ was crystallised with EtOH (45 mL) to afford $3(3.2 \mathrm{~g} ; 4.9$ mmol). Yield 1.1\%. Mp 219-222 ${ }^{\circ} \mathrm{C}$; TLC Rf 0.44; HPLC $99.4 \%$ (r.t. 14.0 min with method A or 11.5 min with method B); ${ }^{13} \mathrm{C}$ NMR (100 MHz, DMSO-d $\left.{ }_{6}\right) \delta 26.4\left(\mathrm{CH}_{3}\right), 43.6$ $\left(\mathrm{NHCH}_{2}\right), 64.7\left(\mathrm{CH}_{2} \mathrm{OH}\right), 69.4\left(\mathrm{CH}_{2} \mathrm{O}\right), 71.0(\mathrm{CHOH}), 83.1$ and 88.4 (C2 and $\mathrm{C} 4), 112.5$ (C6), 145.7 (C3), 151.0 (C1), 157.5 (C5), 168.0, 169.4 and $170.5\left(\mathrm{CH}_{2} \mathrm{CO}\right.$ and $\left.\mathrm{ArCO}\right)$; $\mathrm{MS}$ $\mathrm{m} / \mathrm{z}(\mathrm{ESI}) 674(\mathrm{M}+\mathrm{Na})^{+}, 1325(2 \mathrm{M}+\mathrm{Na})^{+}$; Anal. Calcd for $\mathrm{C}_{17} \mathrm{H}_{23} \mathrm{I}_{2} \mathrm{~N}_{3} \mathrm{O}_{8}$ : C, 31.36; H, 3.56; I, 38.98; N, 6.45. Found: $\mathrm{C}$, $31.41 ; \mathrm{H}, 3.67 ; \mathrm{I}, 38.90 ; \mathrm{N}, 6.33 ;\left(\mathrm{H}_{2} \mathrm{O}, 2.18\right)$. The crop $(6.6$ g) obtained by evaporation of the fractions from preparative HPLC containing almost pure 4 was dissolved in $\mathrm{H}_{2} \mathrm{O}$ (75 $\mathrm{mL})$ and the solution eluted through ion exchange resins (Amberlite Amberjet ${ }^{\circledR}$ 1200H, $9 \mathrm{~mL}$ and Relite ${ }^{\circledR}$ MG1, 6 $\mathrm{mL})$. The neutral eluate was evaporated to dryness and the waxy residue $(10.6 \mathrm{~g})$ was crystallised with EtOH $(66 \mathrm{~mL})$ to afford 4 (5.6 g; $8.6 \mathrm{mmol})$. Yield 1.9\%. Mp 253-254 ${ }^{\circ} \mathrm{C}$; TLC Rf 0.41 ; HPLC $99.0 \%$ (r.t. 20.8 min with method A or 14.5 min with method B); ${ }^{13} \mathrm{C}$ NMR (100 MHz, DMSO-d 6 ) $\delta$
$26.5\left(\mathrm{CH}_{3}\right), 43.6\left(\mathrm{NHCH}_{2}\right), 64.7\left(\mathrm{CH}_{2} \mathrm{OH}\right.$ and $\left.\mathrm{CH}_{2} \mathrm{O}\right), 71.1$ $(\mathrm{CHOH}), 92.5$ (C4 and $\mathrm{C} 6), 123.8(\mathrm{C} 2), 148.2$ (C1 and $\mathrm{C} 3)$, 157.4 (C5), 167.6 and $168.8\left(\mathrm{CH}_{2} \mathrm{CO}\right.$ and $\left.\mathrm{ArCO}\right)$; $\mathrm{MS} \mathrm{m} / \mathrm{z}$ (ESI) $674(\mathrm{M}+\mathrm{Na})^{+}, 1325(2 \mathrm{M}+\mathrm{Na})^{+}$; Anal. Calcd for $\mathrm{C}_{17} \mathrm{H}_{23} \mathrm{I}_{2} \mathrm{~N}_{3} \mathrm{O}_{8}$ : C, 31.36; H, 3.56; I, 38.98; N, 6.45. Found: C, $31.48 ; \mathrm{H}, 3.75 ; \mathrm{I}, 38.86 ; \mathrm{N}, 6.26 ;\left(\mathrm{H}_{2} \mathrm{O}, 3.22\right)$.

\section{$N, N$ '-Bis(2,3-dihydroxypropyl)-5-[(hydroxyacetyl)methyl- amino]-2,4-diiodo-1,3-benzenedicarboxamide (5) (from 1)}

$\mathrm{NaBH}_{4}(0.76 \mathrm{~g} ; 20 \mathrm{mmol})$ was dissolved in a solution of $N, N$ '-bis(2,3-dihydroxypropyl)-5-[(hydroxyacetyl)methylamino]-2,4,6-triiodo-1,3-benzenedicarboxamide (2) (7 g; 9 $\mathrm{mmol})$ in $2 \mathrm{M} \mathrm{NaOH}(100 \mathrm{~mL})$, then $37 \% \mathrm{HCl}(19 \mathrm{~mL})$ was dropped in within $3 \mathrm{~h}$. A brisk hydrogen evolution was observed and the temperature raised from 25 to $50{ }^{\circ} \mathrm{C}$. After further $1.5 \mathrm{~h}$ the yellow solution was concentrated to half volume and directly used for a preparative HPLC (method A) separation to afford $5(1.2 \mathrm{~g} ; 1.84 \mathrm{mmol})$. Yield $20.4 \%$. Mp 160-165 ${ }^{\circ} \mathrm{C}$; HPLC $99.2 \%$ (r.t. 6.8 min with method B); ${ }^{13} \mathrm{C}$ NMR (100 MHz, DMSO-d $\left.{ }_{6}\right) ; \delta 35.0 \quad\left(\mathrm{CH}_{3}\right), 42.7$ $\left(\mathrm{NHCH}_{2}\right), 60.9\left(\mathrm{CH}_{2} \mathrm{CO}\right), 63.8\left(\mathrm{CH}_{2} \mathrm{OH}\right), 70.2(\mathrm{CHOH})$, 92.6 (C2), 100.9 (C4), 127.1 (C6), 144.0, 145.3 and 151.3 (C1, C3 and C5), 168.0, 169.7 and 170.7 (ArCO and $\left.\mathrm{CH}_{2} \mathrm{CO}\right) ; \mathrm{MS} \mathrm{m} / z$ (ESI) $674(\mathrm{M}+\mathrm{Na})^{+}, 690(\mathrm{M}+\mathrm{K})^{+}$; Anal. Calcd for $\mathrm{C}_{17} \mathrm{H}_{23} \mathrm{I}_{2} \mathrm{~N}_{3} \mathrm{O}_{8}$ : C, 31.36; H, 3.56; I, 38.98; N, 6.45. Found: C, 31.60; H, 3.71; I, 36.63; N, 6.31; $\left(\mathrm{H}_{2} \mathrm{O} 2.87\right)$.

\section{5-Amino-N,N'-bis(2,3-dihydroxypropyl)-2,4-diiodo-1,3-ben- zenedicarboxamide (8)}

A $56.3 \%$ solution of $\mathrm{ICl}$ in $15 \%$ aq $\mathrm{HCl}(20.5 \mathrm{~g} ; 71$ mmol) was dropped over $2 \mathrm{~h}$ into a solution of $\mathbf{7} \cdot \mathbf{H C l}(13 \mathrm{~g}$; $35.7 \mathrm{mmol})$ in $\mathrm{H}_{2} \mathrm{O}(300 \mathrm{~mL})$ and $1 \mathrm{M} \mathrm{HCl}(40 \mathrm{~mL} ; 40$ mmol) stirred at $1-4{ }^{\circ} \mathrm{C}$. At the end of the addition, the reaction mixture at $\mathrm{pH} 1$ was evaporated under vacuum and the residue was purified by preparative HPLC (method B) to afford 8 (8.8 g; $15.3 \mathrm{mmol})$. Yield 43\%. Mp $170{ }^{\circ} \mathrm{C}$; TLC: Rf 0.30; HPLC 99.0\% (method C); ${ }^{13} \mathrm{C}$ NMR $(100 \mathrm{MHz}$, $\left.\mathrm{D}_{2} \mathrm{O}\right) ; 44.9\left(\mathrm{NHCH}_{2}\right), 66.4\left(\mathrm{CH}_{2} \mathrm{OH}\right), 72.7(\mathrm{CHOH}), 76.9$ (C2), 86.3 (C4), 116.7 (C6), 145.5 (C5), 150.4 and 151.2 (C1 and C3), 174.5 and 175.4 (ArCO); MS m/z (ESI) $580(\mathrm{M}+$ $\mathrm{H})^{+}, 602(\mathrm{M}+\mathrm{Na})^{+}$; Anal. Calcd for $\mathrm{C}_{14} \mathrm{H}_{19} \mathrm{I}_{2} \mathrm{~N}_{3} \mathrm{O}_{6}$ : C, 29.03; H, 3.31; I, 43.83; N, 7.26. Found: C, 29.31; H, 3.42; I, 42.93; N, 7.47; $\left(\mathrm{H}_{2} \mathrm{O} 6.36\right)$.

\section{N,N'-Bis(2,3-dihydroxypropyl)-5-(hydroxyacetyl)amino-2,4- diiodo-1,3-benzenedicarboxamide (10)}

Acetoxyacetyl chloride (11.0 g; $80.6 \mathrm{mmol})$ was dropped over $20 \mathrm{~min}$ into a solution of $\mathbf{8}(4.8 \mathrm{~g} ; 8.29 \mathrm{mmol})$ in DMA $(50 \mathrm{~mL})$ stirred at $\mathrm{rt}$. After $11 \mathrm{~h}$ at $35^{\circ} \mathrm{C}$, the reaction mixture was evaporated under vacuum, the residue dissolved in $\mathrm{CHCl}_{3}(100 \mathrm{~mL})$ and the solution extracted with $\mathrm{H}_{2} \mathrm{O}(3 \times 100$ $\mathrm{mL})$. The separated organic phase was washed with $8 \% \mathrm{Na}-$ $\mathrm{HCO}_{3}(3 \times 75 \mathrm{~mL})$, dried over $\mathrm{Na}_{2} \mathrm{SO}_{4}$ and evaporated. The residue containing crude 9 was dissolved with $1.5 / 1$ $\mathrm{MeOH} / \mathrm{H}_{2} \mathrm{O}(100 \mathrm{~mL})$ then $1 \mathrm{M} \mathrm{NaOH}(25 \mathrm{~mL} ; 25 \mathrm{mmol})$ was dropped into the solution stirred at $35^{\circ} \mathrm{C}$, at such a rate to maintain $\mathrm{pH} 9.5$ [13]. After $12 \mathrm{~h}$ at $35^{\circ} \mathrm{C}$ the solution was loaded onto ion exchange resin columns (Duolite ${ }^{\circledR} \mathrm{C} 20 \mathrm{MB}$, $20 \mathrm{~mL}$ and Duolite ${ }^{\circledR}$ A30B, $22 \mathrm{~mL}$ ) which were eluted with water. The eluate was concentrated to about $30 \mathrm{~mL}$, then $\mathrm{EtOH}(100 \mathrm{~mL})$ was added. After $15 \mathrm{~h}$ at $10{ }^{\circ} \mathrm{C}$ the precipitate was filtered, washed with EtOH $(2 \times 10 \mathrm{~mL})$ and dried to afford 10 (4.35 g; $6.83 \mathrm{mmol})$. Yield $82 \%$. Mp $235^{\circ} \mathrm{C}$; TLC: 
Rf 0.23; HPLC 98.2\% (method D); ${ }^{13} \mathrm{C}$ NMR (100 MHz, DMSO-d $\left.{ }_{6}\right) ; \delta 42.6\left(\mathrm{NHCH}_{2}\right), 61.7\left(\mathrm{CH}_{2} \mathrm{CO}\right), 63.9\left(\mathrm{CH}_{2} \mathrm{OH}\right)$, 70.2 (CHOH), 85.7 (C2), 90.3 (C4), 118.5 (C6), 139.3 (C5), 144.6 (C3), 149.9 (C1), 168.7, 169.9 and171.6 (ArCO and $\left.\mathrm{CH}_{2} \mathrm{CO}\right) ; \mathrm{MS} \mathrm{m} / z(\mathrm{ESI}) 638(\mathrm{M}+\mathrm{H})^{+}, 660(\mathrm{M}+\mathrm{Na})^{+}$; Anal. Calcd for $\mathrm{C}_{16} \mathrm{H}_{21} \mathrm{I}_{2} \mathrm{~N}_{3} \mathrm{O}_{8}$ : C, 30.16; H, 3.32; I, 39.83; N, 6.59. Found: C, 30.42; H, 3.34; I, 39.88; N, 6.68; $\left(\mathrm{H}_{2} \mathrm{O} 1.2\right)$.

N,N'-Bis(2,3-dihydroxypropyl)-5-[(hydroxyacetyl)methylamino]-2,4-diiodo-1,3-benzenedicarboxamide (5) (from 10)

A solution of 10 (3.8 g; $5.96 \mathrm{mmol})$ in DMF (35 mL) was added with $1.1 \mathrm{M} \mathrm{MeONa}$ in $\mathrm{MeOH}(5.4 \mathrm{~mL} ; 5.96 \mathrm{mmol}$ ) then kept under vacuum to get rid of $\mathrm{MeOH}$. A solution of iodomethane $(0.93 \mathrm{~g} ; 6.56 \mathrm{mmol})$ in DMF $(5 \mathrm{~mL})$ was dropped in $20 \mathrm{~min}$ and, after $24 \mathrm{~h}$ at $\mathrm{rt}$, the solvent was evaporated to obtain a residue which was dissolved in $\mathrm{H}_{2} \mathrm{O}$ (100 mL). After extraction with $\mathrm{CH}_{2} \mathrm{Cl}_{2}(6 \times 100 \mathrm{~mL})$, the aqueous phase was loaded onto ion exchange resin columns (Duolite ${ }^{\circledR}$ C20MB, $15 \mathrm{~mL}$ and Amberlite ${ }^{\circledR}$ IRA 400, $15 \mathrm{~mL}$ ) which were eluted with water. The crude obtained from evaporation to dryness of the eluate was purified by silica gel flash-chromatography $\left(6: 4: 1 \quad \mathrm{CHCl}_{3} / \mathrm{CH}_{3} \mathrm{OH} / 25 \% \quad \mathrm{NH}_{4} \mathrm{OH}\right)$ and the recovered sample was further crystallised with EtOH $(30 \mathrm{~mL})$. After $24 \mathrm{~h}$ at $\mathrm{rt}$, the precipitate was filtered, washed with EtOH $(10 \mathrm{~mL})$ and dried to afford $\mathbf{5}$ as a white product containing $2 \mathrm{~mol}$ of EtOH of crystallisation $(2.3 \mathrm{~g} ; 3.09$ mmol). Yield 52\%. Mp $260{ }^{\circ} \mathrm{C}$ (dec.); HPLC 99.4\% (r.t. 6.8 min with method B); ${ }^{13} \mathrm{C}$ NMR $\left(100 \mathrm{MHz}, \mathrm{D}_{2} \mathrm{O}\right) ; \delta 19.6$ $\begin{array}{lllll}\left(\mathrm{CH}_{3} \mathrm{CH}_{2} \mathrm{OH}\right), & 39.3 & \left(\mathrm{CH}_{3}\right), \quad 44.9 & \left(\mathrm{NHCH}_{2}\right), & 60.1\end{array}$ $\left(\mathrm{CH}_{3} \mathrm{CH}_{2} \mathrm{OH}\right), 63.5\left(\mathrm{CH}_{2} \mathrm{CO}\right), 66.2\left(\mathrm{CH}_{2} \mathrm{OH}\right), 72.6(\mathrm{CHOH})$, 93.8 (C2), 102.6 (C4), 129.7 (C6), 147.2, 149.2 and 152.9 (C1, C3 and C5), 173.2, 174.9 and 176.1 (ArCO and $\left.\mathrm{CH}_{2} \mathrm{CO}\right) ; \mathrm{MS} \mathrm{m} / z(\mathrm{ESI}) 674(\mathrm{M}+\mathrm{Na})^{+}, 690(\mathrm{M}+\mathrm{K})^{+}$; Anal. Calcd for $\mathrm{C}_{17} \mathrm{H}_{23} \mathrm{I}_{2} \mathrm{~N}_{3} \mathrm{O}_{8} 2 \mathrm{C}_{2} \mathrm{H}_{6} \mathrm{O}$ : C, 33.91; H, 4.74; I, 34.12; N, 5.65. Found: C, 33.80; H, 4.57; I, 34.34; N, 5.70; $\left(\mathrm{H}_{2} \mathrm{O}\right.$ $0.8)$.

\section{$N, N$ '-Bis(2,3-dihydroxypropyl)-5-[(hydroxyacetyl)methyl- amino]-4,6-diiodo-1,3-benzenedicarboxamide (6)}

To a solution of 4 (4.17 g; $6.42 \mathrm{mmol})$ in $\mathrm{H}_{2} \mathrm{O}(42 \mathrm{~mL})$ heated at $85{ }^{\circ} \mathrm{C} 1 \mathrm{M} \mathrm{NaOH}(963+642 \mu \mathrm{L} ; 1.605 \mathrm{mmol}$ total) was added at 0 and $1.5 \mathrm{~h}$. After further $2 \mathrm{~h}$ at the same temperature, the solution was neutralised $(1 \mathrm{M} \mathrm{HCl} ; 0.3 \mathrm{~mL})$ and loaded onto an Amberlite ${ }^{\circledR}$ 16.00 XAD column (240 $\mathrm{mL})$ which was eluted at first with $\mathrm{H}_{2} \mathrm{O}(2.1 \mathrm{~L})$ then with 95/5 $\mathrm{H}_{2} \mathrm{O} / \mathrm{CH}_{3} \mathrm{CN}(20 \times 150 \mathrm{~mL})$. The fractions containing the desired product were evaporated to obtain a crop (3.0 g) which was crystallised with $2-\mathrm{BuOH}(24 \mathrm{~mL})$ to afford 6 (1.87 g; $2.87 \mathrm{mmol})$. Yield 44.8\%. Mp 111-114 ${ }^{\circ} \mathrm{C}$; HPLC $95 \%$ (r.t. 11.8 min with method B); ${ }^{13} \mathrm{C} \mathrm{NMR} \mathrm{(100} \mathrm{MHz,}$ $\left.\mathrm{D}_{2} \mathrm{O}\right) \delta 34.8\left(\mathrm{CH}_{3}\right), 42.7\left(\mathrm{NHCH}_{2}\right), 61.6\left(\mathrm{CH}_{2} \mathrm{CO}\right), 63.8$ $\left(\mathrm{CH}_{2} \mathrm{OH}\right), 70.4(\mathrm{CHOH}), 99.3(\mathrm{C} 4$ and $\mathrm{C} 6), 125.9(\mathrm{C} 2)$, 145.3 (C1 and C3), 146.6 (C5), 171.2 and 173.4 (ArCO and $\left.\mathrm{CH}_{2} \mathrm{CO}\right) ; \mathrm{MS} \mathrm{m} / z$ (ESI) $674(\mathrm{M}+\mathrm{Na})^{+}, 690(\mathrm{M}+\mathrm{K})^{+}$; Anal. Calcd for $\mathrm{C}_{17} \mathrm{H}_{23} \mathrm{I}_{2} \mathrm{~N}_{3} \mathrm{O}_{8}$ : C, 31.36; H, 3.56; I, 38.98; N, 6.45. Found: C, 31.51; H, 3.92; I, 38.59; N, 6.38; $\left(\mathrm{H}_{2} \mathrm{O}, 4.12\right)$.

N,N'-Bis(2,3-dihydroxypropyl)-3,4-dihydro-5-iodo-4-methyl3-oxo-2H-1,4-benzoxazine-6,8-dicarboxamide (13)

The fractions discharged from the chromatography to obtain 6 were concentrated to about $30 \mathrm{~mL}$ and subjected to preparative HPLC to afford 13 (0.12 g). Mp 96-98 ${ }^{\circ} \mathrm{C}$; HPLC
$100 \%$ (r.t. 16.5 min with method B); ${ }^{13} \mathrm{C} \mathrm{NMR} \mathrm{(100} \mathrm{MHz,}$ $\left.\mathrm{D}_{2} \mathrm{O}\right) \delta 37.2\left(\mathrm{CH}_{3}\right), 42.2\left(\mathrm{NHCH}_{2}\right), 63.4\left(\mathrm{CH}_{2} \mathrm{OH}\right), 68.9$ (C2), $69.9(\mathrm{CHOH}), 87.1$ (C5), 122.1 (C8), 124.0 (C7), 135.8 and 139.0 (C6 and C4a), 148.1 (C8a), 166.1, 169.3 and 172.2 (ArCO and C3); MS m/z (ESI) $546(\mathrm{M}+\mathrm{Na})^{+}, 1070$ $(2 \mathrm{M}+\mathrm{Na})^{+}$; Anal. Calcd for $\mathrm{C}_{17} \mathrm{H}_{22} \mathrm{IN}_{3} \mathrm{O}_{8}$ : C, 39.02; H, 4.24; I, 24.25; N, 8.03. Found: C, 38.96; H, 4.21; I, 24.03; N, 7.99; $\left(\mathrm{H}_{2} \mathrm{O}, 5.51\right)$.

\section{N,N'-Bis(2,3-dihydroxypropyl)-6-[2-(carboxy)ethoxy]-4- iodo-5-(methylamino)-1,3-benzenedicarboxamide (14)}

Although we did not isolate the compound because of the very low amount of $\mathbf{1 3}$ at disposal, we are confident that $\mathbf{1 4}$ has the proposed structure because of the following experiment. A solution of $13(10 \mathrm{mg} ; 0.019 \mathrm{mmol})$ in $\mathrm{H}_{2} \mathrm{O}(0.5$ $\mathrm{mL})$ was diluted with $2 \mathrm{M} \mathrm{NaOH}(95.5 \mu \mathrm{L} ; 0.19 \mathrm{mmol})$ and heated to $90{ }^{\circ} \mathrm{C}$ for $1 \mathrm{~h}$. The starting material (HPLC r.t. 16.5 min with method B) was almost quantitatively (> 97\%) transformed into a single product, 14 (r.t. $7.6 \mathrm{~min}$ ), which we believe originated by hydrolysis of the lactam bond. Indeed, after cooling to $\mathrm{rt}$ and acidification to $\mathrm{pH} 1$ with $6 \mathrm{M} \mathrm{HCl}$, the lactam moiety was quickly reformed to quantitatively give 13.

\section{Computational Methods}

RHF-SCF gas-phase calculations were carried out with either GAUSSIAN 94 [14] or GAUSSIAN 98 [15] programs. Full geometry optimizations were performed using both $6-31 \mathrm{G}^{*}$ and, as the inclusion of diffuse functions has been shown important for anionic species [16], 6-31+G** basis sets; the basis set for the iodine atoms was that associated with the pseudopotential [17], with a standard double- $\zeta$ LANL2DZ contraction, as internally-stored in the programs. The reliability of the stationary points and the thermodynamics properties (calculated at $298 \mathrm{~K}$ and $1 \mathrm{~atm}$ ) were evaluated by means of the vibrational frequencies at the $\mathrm{HF} / 6-31 \mathrm{G}^{*}$ and, limiting to the structures of the transition states (TS) due to the very time-consuming calculation, at HF/6-31+G** level of theory. The atomic charges were derived from electrostatic potential using the Merz-Kollman-Singh scheme $[18,19]$.

\section{REFERENCES AND NOTES}

[1] a) Felder, E.; Pitrè, D.; Fumagalli, L. Eur. Pat. EP 185130, 1986 b) Felder, E.; Musu, C.; Fumagalli, L.; Uggeri, F. W.O. Pat. WO 8809328, 1988 c) Gallotti, A.; Uggeri, F.; Favilla, A.; Cabrini, M.; de Haën, C. Eur. J. Radiol. 1994, 18, S1-12; d) Alessandroni, L.; Ambrosetti, P.; Argese, M.; Geremia, R.; Moretti, E.; Valle, V.; Ripa, G.; Murru, M. WO Pat. WO 0032561, 2000

[2] Felder, E.; Pitrè, D. U.S. Pat. US 4352788, 1981.

[3] Anelli, P. L; Brocchetta, M.; Calabi, L.; Secchi, C.; Uggeri, F.; Verona, S. Tetrahedron 1997, 53, 11919-1192.

[4] Truce, W. E.; Kreider, E. M.; Brand, W. W. Org. React. 1970, 18, 99-215.

[5] a) Bayles, R.; Johnson, M.; Maisey, R. F.; Turner, R. W. Synthesis 1977, 31-33; b) Bayles, R.; Johnson, M.; Maisey, R. F.; Turner, R. W. Synthesis 1977, 33-34; c) Coutts, I. G. C.; Southcott, M. R. J. Chem. Soc. Perkin Trans. I 1990, 767-771; d) Weidner, J. J.; Weintraub, P. M.; Schnettler, R. A.; Peet, N. P. Tetrahedron 1997, 53, 6303-6312.

[6] Subsequently, when we had at disposal an authentic sample of 6 obtained by rearrangement and reviewed the HPLC chromatograms of the deiodination, we found that a compound with the same retention time was present in the mixture, although in extremely small amount.

[7] The reaction is performed at $95{ }^{\circ} \mathrm{C}$ in $\mathrm{H}_{2} \mathrm{O}$ with $\mathrm{NaOH}(0.1-1.0 \mathrm{~mol}$ equiv. with respect to 2 ) [1b]. 
[8] In the few mg scale reactions performed on $\mathbf{3}$, varying temperature $\left(75-100{ }^{\circ} \mathrm{C}\right)$ and quantity of $\mathrm{NaOH}(0.1-1.0$ mol equiv.) in order to eventually find more proper conditions, evolution of methylamine was observed in any case and at least 1 mol equiv. of base was necessary for the completion. The content of $\mathbf{5}$, which was identified by LC/MS, in the reaction mixtures was never higher than $3 \%$ and the almost unique reaction was hydrolysis to $\mathbf{1 1}$. Accordingly, the recovery of $\mathbf{5}$ from the reaction mixture was not pursued and $\mathbf{5}$ was prepared by an independent synthesis (see Experimental).

[9] Some trials on a few mg scale of $\mathbf{4}$ were performed varying the reaction conditions. At $100{ }^{\circ} \mathrm{C}$ with 0.25 mol equiv. of $\mathrm{NaOH}$ the maximum conversion was obtained at $30 \mathrm{~min}$ when the HPLC composition of the mixture, \%, was: $66.2(\mathbf{6}), 9.5(\mathbf{4}), 10.5(\mathbf{1 3}), 2.9$ (14) and $5.1(\mathbf{1 2})$. At $85{ }^{\circ} \mathrm{C}$; with 0.2 mol equiv. of $\mathrm{NaOH}$ the best result was achieved at $2 \mathrm{~h}$ with the following HPLC composition, \%: $65.2(\mathbf{6}), 12.9(\mathbf{4}), 6.7(\mathbf{1 3}), 2.8(\mathbf{1 4})$ and $5.6(\mathbf{1 2})$. Finally, at 65 ${ }^{\circ} \mathrm{C}$ in $\mathrm{MeOH}$ with $\mathrm{KOH} / \mathrm{MeOH}(0.25$ mol equiv.) no appreciable result was observed because the starting material was suspended. Even after DMF addition in order to have a solution, the reaction was sluggish and the same by-products were observed in large quantities. In the preparative scale reaction (see Experimental) the base was added in two portions to avoid a too high $\mathrm{pH}$ in the mixture. This led to a mixture with the following HPLC composition, \%: $68.1(\mathbf{6}), 12.3$ (4), $5.6(\mathbf{1 3}), 2.1(\mathbf{1 4})$ and 6.8 (12). Accordingly, it is likely that the reaction could be better performed in a buffer around $\mathrm{pH} 10$.

[10] The sum of the HPLC content (\%) of compounds $\mathbf{6}, \mathbf{1 3}$ and $\mathbf{1 4}$ (76.7 mean) [9] gives a rough indication of the extent of rearrangement of $\mathbf{4}$, as the three products derive from such reaction.

[11] Terrier, F. Chem. Rev. 1982, 82, 77-152.

[12] Beak, P. S.; Kerrick, T. D.; Gallagher, J. J. Am. Chem. Soc. 1993, $115,10628-10636$.

[13] These conditions, which are smoother than those usually applied to the deacylation of such esters, i.e. $\mathrm{pH} 10-10.5$ and $40-45{ }^{\circ} \mathrm{C}$, were used after preliminary trials showed an unexpected and important hydrolysis of the hydroxyacetamide bond.

[14] Frisch, M. J.; Trucks, G. W.; Schlegel, H. B.; Gill, P. M. W.; Johnson, B. G.; Robb, M. A.; Cheeseman, J. R.; Keith, T.; Petersson, G. A.; Montgomery, J. A.; Raghavachari, K.; Al-Laham, M. A.; Zakrzewski, V. G.; Ortiz, J. V.; Foresman, J. B.; Cioslowski, J.; Stefanov, B. B.; Nanayakkara, A.; Challacombe, M.; Peng, C. Y.; Ayala, P. Y.; Chen, W.; Wong, M. W.; Andres, J. L.; Replogle, E. S.; Gomperts, R.; Martin, R. L.; Fox, D. J.; Binkley, J. S.; Defrees, D. J.; Baker, J.; Stewart, J. P.; Head-Gordon, M.; Gonzalez, C.; Pople, J. A. Gaussian 94, Revision D.3; Gaussian Inc.: Pittsburgh, PA, 1995.

[15] Frisch, M. J.; Trucks, G. W.; Schlegel, H. B.; Scuseria, G. E.; Robb, M. A.; Cheeseman, J. R.; Zakrzewski, V. G.; Montgomery, J. A.; Stratmann Jr., R. E.; Burant, J. C.; Dapprich, S.; Millam, J. M.; Daniels, A. D.; Kudin, K. N.; Strain, M. C.; Farkas, O.; Tomasi, J.; Barone, V.; Cossi, M.; Cammi, R.; Mennucci, B.; Pomelli, C.; Adamo, C.; Clifford, S.; Ochterski, J.; Petersson, G. A.; Ayala, P. Y.; Cui, Q.; Morokuma, K.; Malick, D. K.; Rabuck, A. D.; Raghavachari, K.; Foresman, J. B.; Cioslowski, J.; Ortiz, J. V.; Stefanov, B. B.; Liu, G.; Liashenko, A.; Piskorz, P.; Komaromi, I.; Gomperts, R.; Martin, R. L.; Fox, D. J.; Keith, T.; Al-Laham, M. A.; Peng, C. Y.; Nanayakkara, A.; Gonzalez, C.; Challacombe, M.; Gill, P. M. W.; Johnson, B.; Chen, W.; Wong, M. W.; Andres, J. L.; Gonzalez, C.; Head-Gordon, M.; Replogle, E. S.; Pople, J. A. Gaussian 98, Revision A.3; Gaussian Inc.: Pittsburgh, PA, 1998.

[16] Chandrasekhar, J.; Andrade, J. G.; Schleyer, P. v. R. J. Am. Chem. Soc. 1981, 103, 5609- 5612.

[17] Hay, P. J.; Wadt, W. R. J. Chem. Phys. 1985, 82, 299-310.

[18] Besler, B. H.; Merz, K. M.; Kollman, P. A. J. Comp. Chem. 1990 11, 431-439.

[19] Singh, U. C.; Kollman, P. A. J. Comp. Chem. 1984, 5, 129-145.

Received: January 23, 2009

(C) Anelli et al.; Licensee Bentham Open.

This is an open access article licensed under the terms of the Creative Commons Attribution Non-Commercial License (http://creativecommons.org/licenses/by-nc/3.0/) which permits unrestricted, non-commercial use, distribution and reproduction in any medium, provided the work is properly cited. 